\title{
Education for Health Back at School Age: The Role of Physical Education
}

\section{Miñana-Signes $\mathbf{V}^{*}$}

Body Languages Didactics Department, Academic Unit of Physical Education, Teacher Training Faculty, University of Valencia, Av. dels Tarongers, 4, 46022, Valencia, Spain

\section{Commentary}

Traditionally, back problems have been addressed from the biomedical area. For a long time the "radiologic-anatomy model" has been considered unusable because they have failed to respond to knowledge about the source of pain or therapeutic approaches used have solved the reduced chronic pain or disability [1].

In this way, it was like the biomedical reductionist approach was replaced by the "biopsychosocial model" [1] which proposes that psychological and social factors along with biological variables in understanding a person's disease are included.

However, back health has focused mainly from the workplace due to high, direct and indirect, costs that cause disability and disability workers.

In contrast and in the educational field, back pain in children was considered rare and therefore was not subject of study [2,3] until the appearance of the first studies on the prevalence of back problems children and adolescents who proved the opposite [4]. That is, the back problems in childhood are high and that failure to act in time could impact worsen in adulthood.

Thus, the school becomes one of the main stages of education and youth socialization, therefore, the World Health Organization [5] has been identified as an effective environment to improve child health. Several authors' specialists in the field have already ratified the school plays a key role to intervene in the prevention and health promotion back [6-8]

In the school, the health back as practical content in the curriculum has been developed exclusively for the area of Physical Education.

According to some authors as Grison [7] argue that the physical education teacher is the best positioned and prepared to observe the position of the students, and to develop an back care education program and preventive action in collaboration with school health services. Despite the limited number of hours possessing the Physical Education $(\mathrm{PE})$ in schools, the role of PE teacher can be important, especially for the application of the principles of back care [9].

The fact that the students are subjected to a variety of risk factors in their daily lives: the transport of incorrect and excessive backpack load, prolonged and improper sitting position, poor postural change, the use of furniture school uniform, inadequate physical activity, poor posture during physical exercise, sedentary lifestyle, high body mass index, reduced mobility and flexibility of muscles and joints, insufficient strength and stability in the trunk musculature, psychosocial factors, etc. $[2,10,11]$ requires that the contents related to the back care and their evaluation play a unifying role in the official curriculum, especially in the field of Physical Education, as claimed several authors [12-14].

For this reason, the main objective is that the students be able to learn, acquire and maintain good health habits to care for their back, and improve their quality of life, reducing and preventing high prevalence of back problems that have.

Currently, despite the extensive knowledge developed in the field of sciences of physical activity and sport, there are no specific guidelines on the prescription of exercise for back health in adolescents
However, some studies suggest developing intervention programs teaching to children from 8 years old to adolescents: basic anatomy and pathology of the back and the basic principles of biomechanical favourable postures during standing, sitting, lying, lifting, pushing and bending, and to use a ludic and active methodology to explain the back care principles making them easy to understand and attractive for the children through the use of games and varied material [15]; to teach and work out the core musculature, proper posture, and spinal alignment [16]; and to practice isometric abdominal exercises and the hollowing abdominal [17].

Therefore, back education programs in students should be conducted by physical education teachers to possess specific knowledge about movement and body posture, be able to address these programs in the educational curriculum, because they can provide instant feedback during physical education classes, to be able to address the postural education from different content such as fitness, gymnastic skills, sports, etc., and because from the area of physical education can be combined on the conceptual back care and procedural content in which students practically apply what they have learned [18].

Despite receiving support teaching related to fitness and back health knowledge, little about the effectiveness of learning and teaching processes on the Physical Education area is known. The literature includes no studies to indicate which variables are associated with effective teaching on back health and therefore should continue studying in this line.

\section{References}

1. Aguado BP, Cosmes LJ, Méndez AF (2010) El dolor lumbar en el año 2009 Rehabilitación 44: 69-81.

2. Cardon G, Balague F (2004) Low back pain prevention's effects in schoolchildren. What is the evidence? Eur Spine J 13: 663-679.

3. 3. King HA (1986) Evaluating the child with back pain. Pediatr Clin North Am 33: $1489-1493$

4. Salminen JJ (1984) The adolescent back. A field survey of 370 Finnish schoolchildren. Acta Paediatr Scand Suppl 315: 1-122.

5. http://www.who.int/healthpromotion/conferences/previous/ottawa/en/\#

6. Ribeiro CC, Conesa AG (2008) Lumbalgia. Prevalencia y programas preventivos en la infancia y adolescencia. Revista Iberoamericana de Fisioterapia y Kinesiología 11: 32-38.

7. Cardon G, De Bourdeaudhuij I, De Clercq D (2009) Back care education in elementary school: a pilot study investigating the complementary role of the class teacher. Patient Educ Couns 45: 219-226.

8. Geldhof E, Cardon G, De Bourdeaudhuij I, Danneels L, Coorevits P, et al.

*Corresponding author: Miñana-Signes V, Body Languages Didactics Department Academic Unit of Physical Education, Teacher Training Faculty, University of Valencia, Av. dels Tarongers, 4, 46022, Valencia, Spain, Tel: +34 963864 490; E-mail: vicente.minana@uv.es

Received August 22, 2015; Accepted October 17, 2015; Published October 19 2015

Citation: Miñana-Signes V (2015) Education for Health Back at School Age: The Role of Physical Education. J Spine 4: 259.doi:10.4172/2165-7939.1000259

Copyright: (c) 2015 Miñana-Signes V. This is an open-access article distributed under the terms of the Creative Commons Attribution License, which permits unrestricted use, distribution, and reproduction in any medium, provided the original author and source are credited. 
(2007) Effects of back posture education on elementary schoolchildren's back function. Eur Spine J 16: 829-839.

9. Balague F, Nordin M, Dutoit G, Waldburger M (1996) Primary prevention, education, and low back pain among school children. Bull Hosp Jt Dis 55:130134

10. Balague F, Troussier B, Salminen JJ (1999) Non-specific low back pain in children and adolescents: risk factors. Eur Spine J 8: 429-438.

11. Trevelyan FC, Legg SJ (2006) Back pain in school children-Where to from here? Appl Ergon 37: 45-54.

12. Tinning R (2001) Physical Education and Back Health: Negotiating Instrumental Aims Andholistic Bodywork Practices. European Physical Education Review 7: 191-205.

13. Handley J (1986) Posture education within a formal physical education lesson. The Bulletin of Physical Education 22: 45-47.

14. Minana-Signes V, Monfort-Panego M (2015) Knowledge on health and back care education related to physical activity and exercise in adolescents. Eur Spine J 18.

15. Cardon GM, de Clercq DL, Geldhof EJ, Verstraete S, de Bourdeaudhuij IM (2009) Back education in elementary schoolchildren: the effects of adding a physical activity promotion program to a back care program. Eur Spine J 16 : 125-133.

16. Fanucchi GL, Stewart A, Jordaan R, Becker P (2009) Exercise reduces the intensity and prevalence of low back pain in 12-13 year old children: a randomised trial. Aust J Physiother 55: 97-104.

17. Harringe ML, Nordgren JS, Arvidsson I, Werner S (2007) Low back pain in young female gymnasts and the effect of specific segmental muscle control exercises of the lumbar spine: a prospective controlled intervention study. Knee Surg Sports Traumatol Arthrosc 15: 1264-1271.

18. Heyman E, Dekel H (2009) Ergonomics for children: An educational program for elementary school. Work: A Journal of Prevention, Assessment and Rehabilitation 32: 261-265. 